\title{
INTERNATIONAL TRADE MEASURES AS AN Alternative to Sanctions Serving Human Rights Protection IN EXTERNAL RELATIONS
}

\author{
BARTOSZ ZIEMBLICKI*
}

\begin{abstract}
INTRODUCTION
Trade sanctions aimed at protecting and promoting human rights can no longer be considered (if they ever could have been) a proper instrument to fight human rights violation in other states. There appears to be a reasonable alternative in other international trade measures, which also may be applied in accordance with the law of the World Trade Organization. Those measures can be divided into two categories: trade incentives adopted under the Enabling Clause and obligation waivers. This article seeks to explore whether either of those legal instruments has the potential to play a significant role in enhancing human rights standards worldwide in terms of their availability and effectiveness.
\end{abstract}

\section{The Problems with Trade SAnctions}

The use of trade sanctions to protect and promote human rights in other states has a long tradition. For example, already in the $19^{\text {th }}$ century some states prohibited international trade in slaves. ${ }^{1}$ Sanctions ordered by the United Nations were launched in 1966 against Rhodesia and became very popular after the end of the Cold War. ${ }^{2}$ Two main problems with trade sanctions are their efficiency and legality.

The efficiency of trade sanctions aimed at human rights protection is widely contested. Surveys prove that they influence the conduct of the governing regimes of states breaching human rights conventions in one out of three cases at best. ${ }^{3}$

DOI: $10.2478 /$ wrlae-2013-0008

* PhD in Law (Wroclaw University); bziemblicki@prawo.uni.wroc.pl.

${ }^{1}$ E Nadelmann, 'Global Prohibition Regimes: The Evolution of Norms in International Society' (1990) 44(4) International Organization 479, 491 and 497.

${ }^{2}$ D Cortright, GA Lopez, The Sanctions Decade, Assessing UN Strategies in the 1990s (Washington 2000) 205-207.

${ }^{3}$ See GC Hufbauer, J Schott, KA Elliott, Economic Sanctions Reconsidered: History and Current Policy (Washington 1990); E Shagabutdinova, J Berejikian, 'Deploying Sanctions 
The legality of trade sanctions must be verified with respect to the law of the World Trade Organization ${ }^{4}$, the United Nations Charter ${ }^{5}$ and, paradoxically, human rights conventions. Trade sanctions are legal in the WTO if ordered by the Security Council of the United Nations. Such a conclusion is based not only on Article 103 of the United Nations Charter, which provides that the obligations of states under the Charter prevail over other obligations, but also on Article XXI (c) of the GATT ${ }^{6}$, which provides that nothing in (that) agreement shall be construed to prevent any contracting party from taking any action in pursuance of its obligations under the United Nations Charter for the maintenance of international peace and security. The legality of sanctions imposed by members of the WTO without a Security Council decision are largely contested, but never really adjudicated in the WTO dispute settlement system. ${ }^{7}$

More controversial is the compliance of the trade sanctions with the United Nations Charter. Ever since the imposition of sanctions against Rhodesia and South Africa many experts have claimed that there is no sufficient nexus between human rights violations in those states and any threat to international peace and security, which would justify such sanctions in accordance with Article 41 of the United Nations Charter. ${ }^{8}$

The last and largest problem with the legality of trade sanctions imposed to protect human rights is their adverse effect. Surveys show that in many cases those trade sanctions not only do not improve the situation of people repressed by their governments, but also their position becomes even worse. One of the widely debated examples is child labour. ${ }^{9}$ Children who had been exploited by being forced to work in mines started to prostitute themselves in order to survive after foreign states forced their authorities to ban work by children. For that reason, some NGOs accused the Security Council itself of human rights violations. ${ }^{10}$

while Protecting Human Rights: Are Humanitarian 'Smart' Sanctions Effective?' (2007) 6(1) Journal of Human Rights 59, 64-69.

4 The law of the World Trade Organization consists of the Marrakesh Agreement Establishing the World Trade Organization signed in Marrakesh, Morocco, on 15 April 1995 and annexes to this agreement.

${ }^{5}$ Signed in San Francisco, United States, on 26 June 1945.

${ }^{6}$ General Agreement on Tariffs and Trade, signed in Geneva, Switzerland, on October 30, 1947.

${ }^{7}$ See WTO cases US - Helms Burton [1996] WT/DS38 and US - Procurement [1997] WT/DS88 and WT/DS95.

${ }^{8}$ E.g. MS McDougal, WM Reisman, 'Rhodesia and the United Nations: The Lawfulness of International Concern' (1968) 62(1) American Journal of International Law 1, 9; Fernando R Tesón, Humanitarian Intervention: An Inquiry into Law and Morality (Transnational 1997); Vera Gowlland-Debbas, Collective Response to Illegal Acts in International Law: United Nations Action in the Question of South Rhodesia (Dordrecht 1990) 471-472; J Delbrück, 'A More Effective International Law or a New 'World Law'? - Some Aspects of the Development of International Law in a Changing International System' (1993) 68(3) Indiana Law Journal, 705, 711; Jochen A Frowein, 'Article 39' in Bruno Simma (ed), The Charter of the United Nations (Oxford 1995) 612.

9 E Lee, 'Globalization and Labour Standards: A Review of the Issues' (1997) 136(2) International Labour Review 173; Denis MacShane, 'Human Rights and Labor Rights: A European Perspective' in Lance A Compa, Stephen F Diamond (eds), Human Rights, Labor Rights and International Trade (1996 Philadelphia) 51.

10 'Unsanctioned Suffering: A Human Rights Assessment of UN Sanctions on Iraq' (1996), $<$ http://www.cesr.org/downloads/Unsanctioned\%20Suffering\%201996.pdf $>$ accessed on 28 
Having in mind the aforementioned problems with trade sanctions as a tool to protect and promote human rights in external relations, it has become critical for states to find alternative measures to achieve their goals.

\section{The Enabling Clause}

Trade incentives provide an alternative tool to trade sanctions with regard to permissible activities of WTO member states serving to protect and promote human rights in external relations. Their application is opposite in function to sanctions because, unlike sanctions, incentives are trade measures designed not to punish trading partners for violations of human rights, but rather to reward them for compliance with human rights standards.

A decade after the adoption of the GATT, an expert panel report revealed that slow economic development of developing states is caused, at least partially, by discriminatory trade policies of developed states. ${ }^{11}$ In response to this challenge, developing states created the Group of 77 and organized a conference to seek solutions to their problems. ${ }^{12}$ The next step was the establishment of the United Nations Conference on Trade and Development (UNCTAD) in 1964 as a permanent intergovernmental body. It begun to work on regulations which would enable providing trade preferences for the developing and the least-developed states. As a result, in 1968 the UNCTAD adopted Resolution no. 21(ii), which called for the establishment of generalized, non-reciprocal and non-discriminatory systems of preferences for developing states with special considerations for the least-developed states. It recognized three goals: to increase their export earnings, to promote their industrialization and to accelerate their rates of economic growth. Preferences were designed mainly for industry as the main beneficiary, with less regard paid to agriculture. ${ }^{13}$ This ongoing discourse between liberal and social currents of thought can be characterized as a rivalry between the ideas of David Ricardo's theory of comparative advantage and the teachings of Argentinean economist Raúl Prebisch, the first Secretary General of the UNCTAD. ${ }^{14}$

Due to the fact that trade preferences for some states are in obvious breach of the most favored nation clause set in Article I of the GATT, it was

March 2012; see also E Shagabutdinova, J Berejikian (n 3) 61; J Müller, K Müller, 'Sanctions of Mass Destruction' (1999) 78(3) Foreign Affairs 43, 49.

${ }^{11}$ GATT, Trends in International Trade: Report by a Panel of Experts (1958) called the Haberler Report; for details see Craig N Murphy, 'What the Third World Wants: An Interpretation of the Development and Meaning of the New International Economic Order Ideology' in Paul F Diehl (ed), The Politics of Global Governance, (Boulder 2001) 266.

12 AN Cole, 'Labor Standards and the Generalized System of Preferences: the European Labor incentives' (2003) 25 Michigan Journal of International Law 179, 185.

${ }^{13}$ GM Grossman, AO Sykes, 'A preference for development: the law and economics of GSP' (2005) 4(1) World Trade Review 41, 43.

${ }^{14}$ NB dos Santos, R Farias, R Cunha, 'Generalized System of Preferences in General Agreement on Tariffs and Trade/Words Trade Organization: History and Current Issues' (2005) 39(4) Journal of World Trade 637, 640 and 644. 
necessary to reconcile Resolution 21(ii) with the law of the GATT. In 1971, the GATT members adopted the Waiver Decision on the Generalized System of Preferences ${ }^{15}$, to be in force for 10 years. ${ }^{16}$ Before the Waiver came to an end, GATT members adopted a decision making this temporary solution a permanent one. The Decision is commonly referred to as the Enabling Clause. ${ }^{17}$ According to its Article 1, notwithstanding the provisions of Article I of the GATT, contracting parties may accord differential and more favorable treatment to developing countries without according such treatment to other contracting parties. The Enabling Clause applies to: 1. Generalized System of Preferences; 2. non-tariff measures governed by the provisions negotiated under the auspices of the GATT; 3 . arrangements among less-developed contracting parties for the mutual reduction of tariffs; 4 . special treatment of the least-developed states. ${ }^{18}$ Out of these cases, the first and the fourth ones give the members of the GATT (now WTO) the opportunity to reward other states for upholding human rights standards. Application of any of the above mentioned trade preferences requires fulfillment of the following conditions: 1. (they) shall be designed to facilitate and promote the trade of developing countries and not to raise barriers to or create undue difficulties for the trade of any other contracting parties; 2. (they) shall not constitute an impediment to the reduction or elimination of tariffs and other restrictions to trade on a mostfavoured-nation basis; 3 . (they) shall in the case of such treatment accorded by developed contracting parties to developing countries be designed and, if necessary, modified, to respond positively to the development, financial and trade needs of developing countries. ${ }^{19}$ Any contracting party taking action based on the Enabling Clause shall notify other contracting parties and afford adequate opportunity for prompt consultations at the request of any interested contracting party. ${ }^{20}$ Furthermore, the developed countries do not expect reciprocity for commitments made by them. ${ }^{21}$

\section{GSPS ADOPTED BY WTO MEMBERS}

Currently, ten states and the European Union maintain general systems of preferences (GSP). They include Australia, Belarus, Japan, Canada, Norway, New Zealand, Russia, United States, Switzerland and Turkey. ${ }^{22}$ The leaders in granting trade preferences are the European Union

\footnotetext{
${ }^{15}$ Waiver Decision on the Generalized System of Preferences, Ministerial Decision of 25 June 1971, L/3545.

${ }^{16}$ See John Jackson, The Jurisprudence of GATT and the WTO (Cambridge 2000) 65-66 and 322-324.

17 Decision of 28 November 1979 on Differential and More Favourable Treatment, Reciprocity and Fuller Participation of Developing Countries, L-4903.

${ }^{18}$ Article 2 of the Enabling Clause.

${ }^{19}$ Article 3 of the Enabling Clause.

${ }^{20}$ Article 4 of the Enabling Clause.

${ }^{21}$ Article 5 of the Enabling Clause.

22 UNCTAD Report General System of Preferences: List of Beneficiaries, UNCTAD/ITCD/TSB/Misc.62/Rev.5, 1. It should be noted, that the legal basis of introduction of GSPs by the developing states (Turkey, Russia, Belarus and Bulgaria) was not the Enabling Clause but the Decision on Waiver of 1999, WTO doc. WT/L/304
} 
and the United States. ${ }^{23}$ Their systems, apart from differences in scale, differ from each other in that they condition the granting of preferences on noneconomic factors - observance of human rights standards. ${ }^{24}$ Conditions are either positive or negative. In the former case, a beneficiary receives trade preferences as a reward for keeping up with human rights protection standards. In the latter case, a beneficiary receives trade preferences unless he fails to keep up with human rights standards. ${ }^{25}$ The first model is followed by the European Union and the second by the United States.

The European Communities originally adopted a GSP for developing states which engaged in fighting the drugs trade. Since 1991, trade preferences for industrial and agricultural products have been granted to Bolivia, Columbia, Ecuador and Peru. ${ }^{26}$ The following year Costa Rica, Salvador, Honduras, Guatemala, Nicaragua and Panama joined the $\operatorname{program}^{27}$, and were followed by Venezuela in $1995 .^{28}$ In 1999, preferences encompassed almost all industrial and agricultural products. ${ }^{29}$ In 2002, Pakistan was added to the list of beneficiaries which were required from then on not only to fight the drugs trade, but also to respect labour rights and environmental protection. ${ }^{30}$ The EC's GSP provided for withdrawal of tariff reductions if a beneficiary was found to be involved in slavery activities, forced labour, money laundering, inefficient customs control, etc. The European Union has in fact withdrawn its preferences twice: in 1997 in respect of Burma and in 2006 in respect of Belarus. ${ }^{31}$ At the same time, the adding of Pakistan to the list resulted in a dispute between the EC and India in the WTO (discussed further), which attracted significant attention of scholars to the question of the legality of the GSPs. ${ }^{32}$

The United States adopted its GSP in $1976 .{ }^{33}$ The last program, which was in force from 2006, expired in 2010. President Obama signed the

\footnotetext{
${ }^{23}$ See G Zagel, 'The WTO and Trade-Related Human Rights Measures: Trade Sanctions vs. Trade Incentives' (2004) 9 Austrian Review of International and European Law 119, 123.

${ }^{24}$ This part of the EU's GSP, which conditions additional trade preferences on human rights observance, is called GSP+.

${ }^{25}$ See Zagel (n 23) 124.

${ }^{26}$ Council Regulation no. 3835/90 of 20 December 1990, OJ 1990, L 370/126.

${ }^{27}$ Council Regulation no. 3900/91 of 16 December 1991, OJ 1991, L 368/11.

${ }^{28}$ Council Regulation no. 3281/94 of 19 December 1994, OJ 1994, L 348/1 and Council Regulation no. 3282/94 of 19 December 1994, OJ 1991, L 348/57.

${ }^{29}$ Council Regulation no. 2820/98 of 21 December 1998, OJ 1998, L 357/1.

${ }^{30}$ Council Regulation no. 2501/2001 of 10 December 2001, OJ 2001, L346/1.

31 W Zhou, L Cuyvers, 'Linking International Trade and Labour Standards: The Effectiveness of Sanctions under the European Union's GSP' (2011) 45(1) Journal of World Trade 63, 64.

${ }^{32}$ See S Charnovitz, 'The Appellate Body's GSP Decision' (2004) 3(2) World Trade Review 239; Grossman, Sykes (n 13); Gregory Shaffer, Yvonne Apea, 'GSP Programmes and Their Historical-Political-Institutional Context' in Thomas Cottier, Joost Pauwelyn, Elisabeth Bürgi (eds) Human Rights and International Trade (Oxford 2005) 488; Jane Bradley, 'The Enabling Clause and Applied Rules of Interpretation' in Thomas Cottier, Joost Pauwelyn, Elisabeth Bürgi (eds) (n 32) 504; L Bartels, 'The WTO Enabling Clause and Positive Conditionality in the European Community's GSP Program (2003) 6(2) Journal of International Economic Law 507, 513.

${ }^{33}$ US Trade Act of 1974.
} 
new GSP into law in October 2011 with retroactive effect from 1 January 2011, giving its beneficiaries the right to reimburse costs resulting from the interruption in the operation of the program. ${ }^{34}$ The new act consists of three sections: the first regulates the president's competences, the second regulates beneficiaries' status, and the third regulates the reimbursement procedure. The list of potential beneficiaries is negative, which means it specifies prerequisites which disqualify them from participation in the program. They include the failure to undertake proper actions to guarantee commonly recognized labor rights standards and to fight child labor, and also those supporting communism or terrorism. ${ }^{35}$ Some states (sovereign territories) ceased to be beneficiaries due to exceeding a particular income index (Hong Kong, Malaysia, Singapore). ${ }^{36}$ Similarly to the EC's GSP, the American program is also accused of being discriminatory in nature. ${ }^{37}$

As was mentioned earlier, the American GSP differs from the European one in that it grants trade preferences if some minimal noneconomic standards are not breached, while the European Union grants trade preferences if some special non-economic standards are met. ${ }^{38}$ What also distinguishes those programs is that the European Union refers to social standards set in the International Labour Organization conventions and environmental protection standards set by the International Tropical Timber Organization, while the United States refers exclusively to internal regulations (it is worth mentioning here that the United States are not even a party to the International Covenant of Economic, Social and Cultural Rights $^{39}$ ). The United States focuses on labor rights, which may raise concerns that their real intention is hidden protectionism and not human rights protection.

According to the UNCTAD Resolution of 1968, general systems of preferences should be general, non-reciprocal and non-discriminatory. However, both the US and the EU GSP programs seem to be discriminatory and require some degree of reciprocity (labour rights observance, fighting terrorism). ${ }^{40}$

\footnotetext{
34 Office of the United States Trade Representative < http://www.ustr.gov/tradetopics/trade-development/preference-programs/generalized-system-preference-gsp $>$ accessed 20 June 2012.

${ }^{35}$ L Bartels, 'The Appellate Body Report in European Communities - Conditions for Granting of Tariff Preferences to Developing Countries and its Implications for Conditionality in GSP Programmes' in Thomas Cottier, Joost Pauwelyn, Elisabeth Bürgi (eds) (n 32) 467.

${ }^{36}$ Grossman, Sykes (n 13) 45.

${ }^{37}$ See H Cullen, 'The Limits of International Trade Mechanisms In Enforcing Human Rights: the Case of Child Labour' (1999) 7(1) The International Journal of Childrens' Rights 1, 11-12; Philip Alston, 'Labor Rights Provisions in US Trade Law: Aggressive Unilateralism?' in Lance A Compa, Stephen F Diamond (eds) Human Rights, Labor Rights and International Trade (Philadelphia 1996) 80.

${ }^{38}$ Cullen (n 37) 12.

${ }^{39}$ Adopted by the United Nations General Assembly on 16 December 1966.

${ }^{40}$ Grossman, Sykes (n 13) 47 and 56.
} 


\section{GSPs in the jurisdiction of the WTO}

In the dispute between India and the EC the compliance of the GSP with WTO law was questioned for the first and, until now, only time. ${ }^{41}$ The system provides for preferences available to all developing states; however, it also includes provisions on additional preferences for those developing states which fight drugs trafficking and trade in slaves (so-called GSP+). India accused the EC of discrimination against developing states by requiring compliance with environmental protection standards as well as fighting the slave trade and drug trafficking. India eventually dropped the first two charges. ${ }^{42}$

Of relevance in this case was the status of the Enabling Clause. If it is to be considered as lex specialis in respect of Article I GATT, the burden of proof would lay with the complainant. If, on the other hand, it is considered an exception to Article I GATT, the burden of proof lays with the respondent. Even though the Enabling Clause is not a temporary regulation, both the panel and the Appellate Body held it to be an exception, and therefore the burden of proof lays with the EC. ${ }^{43}$

The EC put forward three arguments to defend its position: 1. that different needs of the developing states justify differential treatment; 2 . that an objectively justified difference in treatment does not constitute discrimination; 3. that the Enabling Clause does not require granting preferences to all developing states. ${ }^{44}$ The panel found that footnote 3 of the Enabling Clause, referring to the 1971 waiver, justifies the interpretation that preferences should be granted to all developing states. It should also be noted that the panel dismissed the argument of the EC, based on Article XX $\mathrm{b}$ GATT, that the protection of health was a main purpose of the introduced regulation. The panel also found that the EC had breached the necessity test and the prohibition of arbitrary discrimination. This part of the report was not the subject of an appeal.

The Appellate Body found that not-identical treatment of all developing states does not necessarily constitute discrimination. ${ }^{45}$ What is required is equal treatment of developing states which have the same needs. However, an allowed differentiation between developing states must meet additional conditions. The first is an objective standard which serves to compare financial, trade and development needs. The second is that those needs must be of such a kind that trade preferences are the proper instrument to satisfy them. There must therefore be sufficient causality between the granting trade of preferences and the satisfaction of those needs. ${ }^{46}$

41 EC - tariff preferences WT/DS246 (2002). The case European Communities Generalized System of Preferences between Thailand and the EC, WT/DS242 (2001) was settled before a panel was established.

${ }^{42}$ Grossman, Sykes (n 13) 42 and 47.

${ }^{43}$ EC-tariff preferences (2002) Appellate Body Report WT/DS246/AB 99-125.

${ }^{44}$ Grossman, Sykes (n 13) 49.

${ }^{45}$ EC-tariff preferences (2002) Appellate Body Report WT/DS246/AB 165.

46 ibid 163-164. 
Although in its report the Appellate Body introduced additional conditions for permissible differentiation between developing states, it did not apply those conditions in the case at hand. The Appellate Body found that the EC GSP is a closed program for most of the developing states, and therefore it is beyond any doubt discriminatory. ${ }^{47}$

The most important conclusions are the following: firstly, the reference in footnote 3 of the Enabling Clause regarding generalized, nonreciprocal and non-discriminatory trade preferences systems is a biding legal obligation. Secondly, it is permissible to treat the beneficiaries of the program differently, provided such treatment is justified by differences in their needs. ${ }^{48}$

\section{PROBLEMS WITH GSPS}

After the Appellate Body of the WTO found that the EC had breached the Enabling Clause, the EC modified its GSP+. ${ }^{49}$ One of the conditions of being a beneficiary of the program was the filing of an application by the end of October 2005, within 4 months of the program's publication. There were also three substantive conditions: ${ }^{50} 1$. ratification and implementation of 16 human rights treaties; 2. ratification and implementation of at least seven out of eleven good governance conventions; 3 . classification as a vulnerable country (economic condition). This last requirement was met for a given state fulfilling all the following conditions at the same time: 1 . it is not classified by the World Bank as a high-income country; 2. it has no diversified export (whose five largest sections of its GSP-covered imports to the EC represent more than $75 \%$ of the value of its total GSP-covered imports): 3. its GSP-associated imports to the EC represent less than $1 \%$ of the value of total GSP-covered imports to the EC. The beneficiaries of the new GSP+ were the same as under the previous program, with the exception of Pakistan but with the inclusion of Sri Lanka, Moldavia, Georgia and Mongolia.

Even though the legality of the new EC GSP+ was not questioned in the WTO, it has been questioned by academics. In the opinion of Lorand Bartels, the GSP+ breaches the Enabling Clause in at least three ways. Firstly, the purpose of the GSP+ is to compensate the developing states for their efforts to implement human rights protection standards. However, the relationship between this rationale and development, financial and trade needs is difficult to justify. Also, picking the conventions to be implemented in an arbitrary manner seems controversial. ${ }^{51}$ Secondly, the criteria of a developing state with export not exceeding $1 \%$ of the EU's import is not a criteria pertaining to the developing state, but to the EU's trade conditions. ${ }^{52}$ It may therefore be questioned as a basis for permissible differentiation between developing states. Thirdly, the GSP+ may be accused of the very

\footnotetext{
47 ibid 187-188.

${ }^{48}$ Grossman, Sykes (n 13) 55.

${ }^{49}$ See L Bartels, 'The WTO Legality of the EU's GSP+ Arrangement' (2007) 10(4) Journal of International Economic Law 869, 869

${ }^{50}$ Complex article 9 of the Council Regulation no 980/2005 of 27 July 2005, OJ 2005, L169/1.

${ }_{51}$ Bartels (n 49) 875-882.

52 ibid 882 .
} 
same offense for which its previous GSP+ was held incompatible with WTO law. The list of beneficiaries was closed for many years after the time for applications, which was just a few months, had expired. Therefore, the program may be considered as not generalized. ${ }^{53}$ Umut Turksen shares this view. He indicates even more incompatibilities of the GSP+ with WTO law. ${ }^{54}$ Despite serious doubts regarding compliance of the current EC GSP+ with WTO law in respect of the report contained in EC-preferential tariffs, to date the legality of the program has not been questioned in the WTO.

Apart from legal concerns regarding the functioning of the GSPs, there are also economic controversies. Firstly, the benefits from preferential tariffs are balanced by the increase in costs of compliance with additional conditions for joining the program. ${ }^{55}$ Secondly, the influence of the preferential tariffs on the economic development of developing states is contested. Some authors suggest that despite their weak market position, states fully respecting liberal international trade develop more rapidly than those enjoying protectionist practices, even if their partners do not return the favor. ${ }^{56}$ On the other hand, the GSPs of both the EU and the US emphasize labor rights. Some surveys indicate a strong correlation between protection of the rights of employees and economic growth, because better-paid workers have greater purchasing power, which stimulates the economy. ${ }^{57}$ Scholars do not, however, agree on this point. ${ }^{58}$ Some claim that the conditions pertaining to human rights protection introduced into the GSPs of the EU and the US are inspired by protectionist motivations rather than by a desire to protect human rights. ${ }^{59}$

The EU is the largest importer of food in the world, and its trade preferences benefit the majority of the world's states. However, using trade preferences as an instrument of deterrence from human rights abuses raises concerns. As mentioned above, the EU suspended those preferences to punish Burma and Belarus. Burma violated freedom of speech and of conscience, practiced forced labor and tortured its citizens. Belarus violated labour rights. ${ }^{60}$ Economic statistics in both cases show that the trade volume of those states not only did not decrease, but rather increased significantly

\footnotetext{
53 ibid 882-884.

${ }^{54}$ See U Turksen, 'The WTO Law and the EC's GSP+ Arrangement' (2009) 43(5) Journal of World Trade, 927, 967-970.

${ }^{55}$ Grossman, Sykes (n 13) 61.

56 See D Dollar, 'Outward-Oriented Developing Economies Really Do Grow More Rapidly: Evidence from 95 LDCs, 1976-1985' (1992) 40(3) Economic Development and Cultural Change 523; JD Sachs, AM Warner, 'Economic Reform and the Process of Global Integration' (1995) 26(1) Brookings Papers on Economic Activity 1; S Edwards, 'Openness, Trade Liberalization, and Growth in Developing Countries' (1993) 31(3) Journal of Economic Literature 1358; JA Frankel, D Romer, 'Does Trade Cause Growth' (1999) 89(3) American Economic Review 379.

${ }^{57}$ See Cole (n 12) footnote 146.

${ }^{58}$ Critically: James Harrison, The Human Rights Impact of the World Trade Organization (Hart Publishing, 2007) 78-81.

${ }^{59}$ See M Khor, 'The World Trade Organization, labour standards and trade protectionism' (1994) 41 Third World Resurgence 30, 30-34; see also J Harrison, 'GSP Conditionality and Non-Discrimination' (2003) 9(6) International Trade Law and Regulation 159, 163.

${ }^{60}$ Zhou, Cuyvers (n 31) 69.
} 
during the period in which trade preferences were suspended. Burma is a state rich in oil, gas, minerals and timber and its main trade partners are China and Thailand. Belarus trades mainly with Russia. What is most disturbing is that during the suspension of preferences both states' trade volumes with the EU increased as well. ${ }^{61}$

\section{THE KIMBERLEY WAIVER AS AN EXAMPLE OF OBLIGATIONS WAIVER}

Trade incentives are not the only tool for supporting the promotion of human rights abroad. Another instrument recognized by the WTO is obligations waiver. ${ }^{62}$ The most famous example of its use is the Kimberley Waiver, regulating trade in diamonds.

International trade in diamonds involves numerous human rights abuses in West Africa. The problem especially pertains to Angola, Ivory Coast, Congo, Liberia and Sierra Leone. The first diamond was found in Africa in 1863. In 1888, Cecil Rhodes established the De Beers Corporation, currently the largest diamond seller in the world. The largest diamond markets are in New York, Paris and Antwerp. How does the trade in diamonds influence human rights? Corruption and smuggling of so-called blood diamonds ignite revolutions and armed conflicts by providing financing to anti-government forces, structured similarly to organized crime. These conflicts result in political instability, economic stagnation, the threat of hunger to large groups of people and mass migrations. The income from diamonds, instead of elevating living standards in these societies, is collected by small groups of elites and serves to fuel civil wars. Side effects are murders, rapes, mutilations of civilians and abductions of children to conscript them into military units or force to labour. ${ }^{63}$ When the UN imposed economic sanctions on some of those states, diamonds were smuggled and sold as coming from legal sources in Congo, Guinea, Ivory Coast and Gambia. ${ }^{64}$

The scale of the tragedies befalling the citizens of western African states was brought to the attention of the international community by the efforts of the non-governmental organizations Global Witness (based in London) and Partnership Africa Canada (based in Ottawa). ${ }^{65}$ The trade in blood diamonds was publicized mostly by Global Witness, which revealed that the government of Belgium and the De Beers Corporation were involved in this shady business. ${ }^{66}$ On 29 January 2001, the UN General Assembly passed Resolution no. $55 / 56^{67}$ on the role of diamonds in fuelling conflict: breaking the link between the illicit transaction of rough diamonds

\footnotetext{
61 ibid 71 and 76.

${ }^{62}$ Regulated in Marrakech Agreement, Article IX (3); also GATT Article XXV (5).

${ }^{63}$ Krista N Schefer, 'Stopping Trade in Conflict Diamonds: Exploring the Trade and Human Rights Interface with the WTO Waiver for the Kimberley Process' in Thomas Cottier, Joost Pauwelyn, Elisabeth Bürgi (eds) (n 32) 400.

64 ibid 402-410.

65 ibid 411.

66 'A Rough Trade: The Role of Companies and Governments in the Angolan Conflict' (1998) < http://www.globalwitness.org/library/rough-trade> accessed 20 June 2012.

${ }^{67}$ United Nations document A/RES/55/56.
} 
and armed conflict as a contribution to prevention and settlement of conflicts, and called all its members to put into place control mechanisms for the diamond trade (the UN also adopted Resolution no. 56/263 on 26 February $2002^{68}$ ). The purpose was to prevent situations in which financial assets would be spent on providing arms and fuel to rebels.

African states quickly realized how dangerous the trade in blood diamonds was, and not only to the states directly involved in this trade. Mass migrations of refugees, threats to foreign investments and threats to ruling governments resulted in the attraction of international attention. In May 2000, a conference was held in Kimberley, South Africa, attended by representatives of interested states, non-governmental organizations and private companies trading in diamonds. Diamond is a pure carbon with a unique crystal structure, and there is no method for determining its origin. The purpose of the conference was to establish a diamond certification system that would prevent international trade in diamonds extracted or mediated by uncertified entities. In the Declaration of Interlaken of 5 November 2002, the date of entry into force of the certification scheme was set for 1 January 2003.

The Kimberley Process Certification Scheme consists of 6 sections and 3 annexes. ${ }^{69}$ It includes many recommendations, but few obligations. It requires the parties to introduce a diamond certification scheme consisting of: 1. the title 'Kimberley Process Certificate'; 2. a clause of compliance with the Kimberley Process; 3. country of origin; 4. translation of the certificate into English; 5. a unique number; 6. date of issuance and expiry date; 7. name of the issuing authority; 8 . identification of the exporter and importer; 8 . the carat weight and monetary value in US dollars; 9. a tariff code and cargo description; 10. the number of parcels in shipment; 11. validation of the certificate by the Exporting Body. ${ }^{70}$ It should also be tamper and forgery resistant. ${ }^{71}$ The Scheme provides for optional elements of certificates. ${ }^{72}$ The process requires from signatories not only the introduction of certificates, but also verification of whether they are consistent with the actual shipment. ${ }^{73}$ Section IV regulates internal controls and obliges the states to designate an Importing and an Exporting Authority (b), collect trade data (e) and penalize breaches against the Scheme (d). Section $\mathrm{V}$ obliges states to cooperate by exchanges of information (a), compile statistical data (b) and cooperate in law enforcement (g). Certification requirements represent a compromise between efficient control on the one hand and not overburdening states with excessive administrative obligations on the other. ${ }^{74}$ The most fierce critics of the Process are nongovernmental organizations, which allege that it lacks independent, regular

\footnotetext{
${ }^{68}$ United Nations document A/RES/55/263.

${ }^{69}$ Kimberley Process Certification Scheme $<$ http://www.kimberleyprocess.com $>$ accessed 20 June 2012.

${ }^{70}$ Annex I, A (i-iv, vi-xiv).

${ }^{71}$ Annex I, A (v).

${ }^{72}$ Annex I, B.

${ }^{73}$ Section III.

${ }^{74}$ Schefer (n 63) 413.
} 
monitoring and that the certification is applied exclusively in international trade, not in domestic. ${ }^{75}$

Currently there are 50 parties to the Kimberley Process, but because one of them is the EU, there are 76 states participating, including all of the world's largest diamond exporters and importers. ${ }^{76}$ Section III(c) of the Kimberley Process prohibits the parties from trading in diamonds with states that are not parties to the Process. Such regulation constitutes an obvious breach of a fundamental principle of international trade: the most favored-nation clause. On the other hand, since there is no method for distinguishing a blood diamond from a regular diamond, it is difficult to imagine a different way of eliminating the trade in blood diamonds. According to the Marrakesh Agreement ${ }^{77}$, in exceptional circumstances the Ministerial Conference may decide to waive an obligation imposed on a member, provided such decision is taken by $3 / 4$ of the members. ${ }^{78}$ Before voting, the request for a waiver should be submitted to the relevant council (Council for Trade in Goods, Council for Trade in Services, Council for TRIPS) for a report. ${ }^{79} \mathrm{~A}$ decision by the Ministerial Conference granting a waiver should state the exceptional circumstances justifying such a decision, the terms and conditions governing the application of the waiver and the date on which the waiver shall terminate. Any waiver granted for more than one year should be reviewed by the Ministerial Conference within one year of its granting, and after that every year until its expiry. ${ }^{80}$ Despite numerous obligation waivers granted so far in the WTO, in practice they do not have much influence on the organization's functioning as approximately $80 \%$ of them refer only to tariff classification modifications. ${ }^{81}$ During the adoption of the Kimberley Process, a debate begun on whether a WTO obligation waiver was necessary in this situation. The EC and Switzerland opposed such waivers waiver, arguing that it should not be a priori assumed that the Kimberley Process is in breach of WTO law. They suggested waiting and seeing whether its compliance with WTO law would be questioned, and if so, what the decision of the panel and Appellate Body would be. ${ }^{82}$ However, the determination of the United States and Canada resulted in an application for a waiver being submitted to the WTO. The Kimberley Waiver was granted in a General Council Decision of 2003. ${ }^{83}$

The Waiver itself refutes that its existence determines the noncompliance of the Kimberley Process with WTO law. It was introduced for 4 years ${ }^{84}$ and has been annually prolonged ever since. The Waiver covers only the GATT. However, according to Krista N. Schefer, ${ }^{85}$ it breaches the

\footnotetext{
75 ibid 415.

${ }^{76}$ Data from the website $<$ http://www.kimberleyprocess.com> accessed 20 June 2012.

${ }^{77}$ Marrakesh Agreement Establishing the World Trade Organization, signed in Marrakesh, Morocco, on 15 April 1994.

${ }^{78}$ See subnote 62.

${ }^{79}$ Marrakech Agreement, Article IX (3)(b).

${ }^{80}$ Marrakech Agreement, Article IX (4).

${ }^{81}$ Schefer (n 63) 442.

82 ibid 394 and 443.

83 Waiver concerning Kimberley Process Certification Scheme for rough diamonds, General Council Decision of 15 May 2003, WT/L/518.

${ }^{84}$ From 1 January 2003 to 31 December 2006.

${ }^{85}$ Schefer (n 63) 444-447.
} 
Agreement on Technical Barriers to Trade (TBT) ${ }^{86}$ and Agreement on Import Licensing Procedures. ${ }^{87}$ She also claims that a waiver, which is a temporary measure in its nature, cannot over a longer period be a substitute for a permanent, systemic solution and risks other improvised corrections. ${ }^{88}$ Further concerns are raised by the premise of extraordinary circumstances required to grant a waiver. Just because a problem is grave and complex does not make it extraordinary. This is why an obligations waiver cannot be considered as an efficient and universal tool for human rights protection, an argument supported by the fact that the Kimberley Waiver remains one of few examples of such a quick and direct reaction by the WTO to human rights abuses. What is more, a phrase in the Kimberley Waiver that the international certification scheme for rough diamonds must be consistent with international law governing international trade ${ }^{89}$ seems to prioritize international trade law over international human rights law. Schefer argues that a better solution from the perspective of human rights protection would be to follow the Swiss suggestion and enable direct confrontation between WTO law (especially Articles XX and XXI of the GATT) with human rights law. ${ }^{90}$ If it turned out that the Kimberley Waiver breached WTO law, there would be no doubt that this organization contributed to human rights violations, since it is hard to imagine a more drastic example of human rights abuses and measures better suited to fight them.

Kevin R. Gray, on the other hand, does not agree with the argumentation presented above. In his opinion, trade in blood diamonds cannot serve as an example representing the links between international trade law and international human rights law. The violence against civilians in western Africa should be regarded as a humanitarian crisis rather than traditional human rights abuses. Besides, trade in blood diamonds is only part of a broader context of attacks on civilian populations, and human rights abuses accompanying mining and distribution of the gems do not constitute the core of the problem. ${ }^{91}$ Sales of diamonds generate financial income for rebels, with which they purchase arms, fuel and other supplies that they then use to terrorize civilian populations. The nexus between diamonds and human rights abuses is therefore not direct. In his view, human rights abuses in such circumstances, however outrageous, may be considered as merely side effects of military conflicts. ${ }^{92}$

\footnotetext{
${ }^{86}$ Annex 1A to the Marrakesh Agreement.

${ }^{87}$ Annex 1A to the Marrakesh Agreement.

${ }^{88}$ Schefer (n 63) 444-447.

${ }^{89}$ Preamble of the Kimberley Process Certification Scheme.

${ }^{90}$ Schefer (n 63) 450.

${ }^{91}$ Kevin R Gray, 'Conflict Diamonds and the WTO: Not the Best Opportunity to be Missed for the Trade-Human Rights Interface' in Thomas Cottier, Joost Pauwelyn, Elisabeth Bürgi (eds) (n 32) 451-452.

92 ibid 461.
} 


\section{The Cotonou AgREement WAIVER}

WTO law does not preclude the existence of regional trade agreements (RTAs). Article XXIV (4) of the GATT provides that the contracting parties recognize the desirability of increasing freedom of trade by the development, through voluntary agreements, of closer integration between the economies of the countries - parties to such agreements. They also recognize that the purpose of a customs union or of a free-trade area should be to facilitate trade between the constituent territories and not to raise barriers to the trade of other contracting parties with such territories. The compliance of the RTAs with the GATT depends, however, on further conditions (Article XXIV (5)-(9) GATT).

An important RTA impacting the promotion of human rights in external relations is the Cotonou Agreement ${ }^{93}$ between the European Union and 77 African, Caribbean and Pacific states (ACP). The Agreement was signed in Benin on 23 June 2000, for a period of 20 years. The legal basis for the European Union to sign it was Article 208 of the Treaty on the Functioning of the European Union (former Article 188 of the Treaty establishing the European Community) on development cooperation policy with the objective of eradicating poverty. The three foundations of the Agreement are: 1. the political dimension; 2. development strategies; 3. economic and trade cooperation. The Cotonou Agreement replaces the four Lomé Conventions of 1975, which themselves replaced the Yaoundé Convention of 1963.

Similarly to its predecessors, the parties to the Cotonou Agreement were granted an obligations waiver, ${ }^{94}$ as the preferences it gave were covered by neither the GSP, nor by Article XXIV of the GATT. ${ }^{95}$ Interestingly, when the United States adopted the African Growth Opportunity Act in 2000, they did not apply for a waiver, even though its content is similar to that of the Cotonou Agreement. This Act raises concerns as to its compliance with the Enabling Clause, ${ }^{96}$ yet it has never been challenged in the WTO.

The most relevant modification in the Cotonou Agreement, when compared with the Lomé Convention, is the introduction of reciprocity. ${ }^{97}$ According to Article 34 (1) of the Agreement, the aim of economic and trade cooperation is to foster integration of the ACP states into the global economy. The Agreement was strongly criticized by non-governmental organizations and some of the potential beneficiaries due to the reciprocity

\footnotetext{
93 Partnership Agreement between the members of the African, Caribbean and Pacific Group of States of the one part, and the European Community and its Member States, of the other part, signed in Cotonou, Benin, on 23 June 2000, OJ 2000, L 317/3.

94 Waiver concerning the ACP-EC Partnership Agreement, Ministerial Decision of 14 November 2001, WT/MIN(01)/15.

${ }^{95}$ For more details see FAST Matambalya, S Wolf, 'The Cotonou Agreement and the Challenges of Making the New EU-ACP Trade Regime WTO Compatible' (2001) 35(1) Journal of World Trade 123, 133-135.

${ }^{96}$ See Harrison (n 59) 162.

97 JC Nwobike, 'The Emerging Trade Regime Under the Cotonou Partnership Agreement: Its Human Rights Implications' (2006) 40(2) Journal of World Trade 291, 294.
} 
arrangement, which is considered a major threat to poverty reduction and development. ${ }^{98}$

The connection between the Cotonou Agreement and human rights protection is even less direct than in the case of the Kimberley Waiver. The Cotonou Agreement does not directly condition assistance on the observance of human rights, yet the agreement emphasizes that cooperation shall be directed towards human rights protection. ${ }^{99}$ It is therefore another WTO instrument allowing for preferential treatment of developing states which does improve the standard of living in those states and results in improved human rights standards. ${ }^{100}$ It serves therefore human rights goals to an equal degree as trade goals. The Kimberley Waiver and the Cotonou Waiver are examples of a new trend of applying obligations waivers in issues of greater weight than tariff classifications modifications.

\section{SUMMARY AND CONCLUSIONS}

The members of the World Trade Organization, which are usually also parties to human rights conventions, occasionally engage in protection and promotion of human rights abroad. The traditional trade measures used for these purposes were trade sanctions. In recent years, however, both their efficiency and legality have been contested. States have started to seek alternatives.

The first such alternative is trade incentives (Generalized System of Preferences). They exempt trade measures from the most favored nation clause and allow developed states to offer trade preferences to the developing and the least developed states. The legal basis for the adoption of GSP is the Enabling Clause adopted by WTO members in 1979. Among the developed states, two WTO members (the US and the EU) grant trade preferences conditioned on observance of human rights standards. To date, only once have their programs been challenged in the WTO (in the $E C$ trade preferences case). India complained about the discriminatory nature of the EC program, and both the panel and the Appellate Body shared its view. Even though the EC modified its GSP, it seems that it still violates the Enabling Clause. The same is true for the United States.

Apart from the legality of the EU and US GSP programs, their effectiveness is equally contested. One flaw is that the participation in programs generates costs that cancel out the benefits. Another issue is that surveys indicate that suspension of participation in the programs did not negatively affect the punished states' economies. It should also be added that some observers question the intentions of the EU and US, suggesting

\footnotetext{
98 See for example ActionAid International, 'Trade Traps: Why EU-ACP Economic Partnership Agreement pose a threat to Africa's development' $<$ http://www.actionaid.org.uk/doc lib/trade traps.pdf $>$ accessed 20 June 2012; Nwobike (n 97) 295.

${ }^{99}$ Articles 9 and 96.

${ }^{100}$ Schefer (n 63) 443.
} 
that their programs are fueled by protectionist motivations rather than by the desire to help states in need.

The second trade measure alternative to sanctions is obligations waivers. According to Article IX(3) of the Agreement establishing the WTO, in exceptional circumstances the Ministerial Conference may decide to waive an obligation imposed on a member. Even though this instrument is generally used for tariffs classification modifications, the Kimberley Waiver of 2003 serves to fight the trade in blood diamonds. It allows the parties to discriminate against WTO members which are not parties to the Kimberley Process Certification Scheme. Another example of using obligation waivers to promote human rights is the Cotonou Agreement. It allows the EU to give special trade preferences to the developing states of Africa, the Caribbean and the Pacific.

Even though these waivers have never been challenged in the WTO dispute settlement system, the major problem with the application of waivers in general is that they are conditioned on extraordinary circumstances. It is a condition difficult to fulfill, and makes these measures practically inapplicable. A particular problem pertaining to the Cotonou Agreement is its trade reciprocity requirement, strongly criticized as nullifying the potential benefits to states in need. It should also be noted that classifying the blood diamonds problem as a case of human rights abuse or as a humanitarian crisis is a purely academic dispute, irrelevant to the core of the issue. 